\title{
Maize Production under No-Tillage System in Nepal
}

\author{
Tika Bahadur Karki*, Jiban Shrestha \\ Nepal Agricultural Research Council, National Maize Research Program, Rampur, Chitwan, Nepal \\ *Corresponding author: tbkarki2003@gmail.com
}

Received October 11, 2014; Revised November 12, 2014; Accepted December 28, 2014

\begin{abstract}
Maize (Zea mays L.) is the second most important staple food crop after rice in Nepal. In Nepal, maize is grown under intensive tillage ssystem of 2-3 ploughings for land preparation and atleast two intercultural operations for weeding and earthling-up operation. Alternative to conventional tillage system, no-till system is a specialized type of conservation tillage consisting of a one-pass planting and fertilizer operation in which the soil and the surface residues are minimally disturbed. No-tillage maize production conserves soil and water and reduces capital investment in machinery for land preparations and intercultural operations, but most important to many producers, no-tillage can improve maize yields. However, very limited works have been done so far in Nepal. Therefore, an attempt has been made in this article to highlight the importance of no till in maize in the hills of Nepal and some of the practical tips to adopt the no- till maize production system in Nepal.
\end{abstract}

Keywords: maize production, no tillage and Nepal

Cite This Article: Tika Bahadur Karki, and Jiban Shrestha, "Maize Production under No-Tillage System in Nepal.” World Journal of Agricultural Research, vol. 2, no. 6A (2014): 13-17. doi: 10.12691/wjar-2-6A-3.

\section{Introduction}

Maize (Zea mays L.) is the second most important staple food crop after rice in Nepal. The consumption of maize is $45.5 \mathrm{~kg} / \mathrm{capita} /$ day as against 37.9 in wheat and 78.0 in rice in Nepal. Maize only contributes about $43.5 \%$ of total edible food production in the country [1]. However, the statistics shows that the contribution of maize to agricultural gross domestic with maize area and production nearly doubling. In the hills, maize is grown under intensive tillage ssystem of 2-3 ploughings for land preparation and atleast two intercultural operations for weeding and earthing-up operation [7]. Intensive tillage causes excessive breakdown of aggregates leading to soil erosion in higher-rainfall area. Intensive tillage can also have a negative impact on environmental quality by accelerating soil carbon loss and green house gas emission [13]. With recent increases in fuel prices, tillage now accounts for a higher proportion of production costs than harvesting does [5]. Such systems have fueled interest in finding tillage systems that minimize negative impacts to the environment while sustaining economic crop productivity. More recently, conservation tillage (no tillage with residue retention) was identified in recent literature reviews [6].

Wilhelm et al. [17] as being necessary if producers hope to increase or maintain soil organic carbon (SOC) levels. West and Post [16] concluded in their extensive review of results from 67 long-term experiments from around the world that when management was changed from conventional tillage to a no-till system, a significant increase in SOC was obtained, but in their analysis they found approximately $85 \%$ of that change occurred in the surface $7-\mathrm{cm}$ of soil. It is also important to note that only six of their 276 paired comparisons were from sampling depths greater than $30-\mathrm{cm}$. West and Post [16] also noted that increased cropping diversity appeared to increase SOC levels, but these increases were not as much as those obtained from utilization of some form of reduced or notill system. Recent reports by Pikul et al. [12] and Varvel [15] from long-term conventionally tilled experiments indicated similar results to those of West and Post [16] in that even with increased cropping diversity, SOC levels were reduced or at best maintained in the surface $30-\mathrm{cm}$ after 15-20 years.

The no-till system is a specialized type of conservation tillage consisting of a one-pass planting and fertilizer operation in which the soil and the surface residues are minimally disturbed [10]. The surface residues of such a system are of critical importance for soil and water conservation. In the sloppy terraces, the planting is done by manually operated Jab planter that makes a small hole of 2-5 cm depth and drills the seed into it. According to Lal [8], no-tillage systems eliminate all pre-planting mechanical seedbed preparation except for the opening of a narrow (2-3 cm wide) strip or small hole in the ground for seed placement to ensure adequate seed/soil contact. The entire soil surface is covered by crop residue mulch.

\section{Advantages of No-Tillage in the Maize Based System}

No-tillage maize production conserves soil and water and reduces capital investment in machinery for land preparations and intercultural operations, but most important to many producers, no-tillage can improve maize yields. For example, in a 15-year study at Virginia Tech, no-tillage maize planted into a rye cover crop out- 
yielded conventional tillage maize by 16 percent [9]. In a three-year University of Maryland study, no-tillage maize in a small-grain/double-crop soybean stubble out-yielded conventional tillage maize by 28 bushels per acre i.e. 1.75 $\mathrm{Mg} \mathrm{ha}^{-1}$. In a study carried out by Karki et al. [7] in the western hills of Nepal, revealed that the grain yield of maize in its' $4^{\text {th }}$ year under maize-rapeseed system was significantly affected by tillage methods, where NT produced the grain yield of 5.212 as against CT with 4.752 $\mathrm{Mg} \mathrm{ha}^{-1}$. In the same experiment, the test weight (1000 grain weight) of maize was also recorded the higher in NT with 263.9g as compared to 262.5g in CT. Moreover, the result obtained in the first season experiment of tillage and weed management methods on spring maize at Rampur, Chitwan by Shrivastav et al. [14] revealed that the grain yield and crop phonological duration did not vary due to tillage methods.

No-till leaves the soil undisturbed from harvest to planting. This practice also leaves crop residues on the surface after planting, which promotes infiltration of rain falling months [2]. Rust and Williams in a Technical Note mentioned that residue also prevents runoff and erosion through retention of water (acting like a sponge, keeping water within the soil and not flowing across the surface) and detention of water (like a dam, holding water back from creating more runoff).

Adding organic matter through residue can improve soil structure and fertility. The residue cover also provides for better flotation of equipment over the field surface, allowing planting and harvesting to occur under wetter soil conditions. Crop residues on the surface of no-till soils may act as an insulator, further decreasing soil temperature and reducing evaporation from the soil surface [3].

However, it must be noted that planting or harvesting when the soil is too wet may contribute to soil compaction. In our context very few no-till based studies on maize have been done so far to date. However, based on the review of the works done across the globe, some of the pertinent issues are there on NT maize in Nepal. Obtaining significant yield increases from no-tillage requires sound management decisions and attention to some unique problems; therefore an attempt has been made in this article to highlight the issues and their practical solutions.

\section{Management Decision of No-Tillage}

\subsection{Preparedness of the Farmer}

Farmers should be mentally prepared with adequate knowledge to abort the risks of shifting to NT from CT. Use of high yielding genotypes of maize preferably hybrids along with higher level of nutrients and weed management through herbicides are the new interventions to be made in order to have the good harvest under NT. Use a piece of land (10\%) for the first time in practicing the CT.

\subsection{Liming for Acidic Soils}

A soil $\mathrm{pH}$ of 6.0 to 6.5 is needed for best results from no-tillage, because besides the multi-advantage of neutral $\mathrm{pH}$, triazine herbicides like atrazine as pre-emergence herbicide used in maize also require a $\mathrm{pH}$ in this range for best performance. This $\mathrm{pH}$ range is also recommended for maximizing nutrient availability to the maize crop. If continuous no-tillage is to be practiced for several years, soil samples should be collected annually from the top 15 $\mathrm{cm}$ of soil.

\subsection{Fertilizer Management}

Of the three major nutrients, phosphorus and potash should be applied as per the annual soil test results. Interestingly, surface application of phosphate and potash in no-till has proved to be an effective application method. In no-till, phosphate and potash will move downward in the soil very gradually. This movement begins only after the surface inch or two of soil becomes high in these nutrients. However, crops will not suffer any deficiency provided a good soil testing program is followed and the nutrients are applied as recommended for broadcast application. Evidence of this comes from a long-term tillage study conducted at MU's Greenley Center in northeast Missouri (Table 1). The heavy crop residues from a no-till system create an excellent crop rooting environment in the soil surface. Thus, the crop is able to take up sufficient nutrients from the surface soil.

Table 1. Phosphorus stratification occurs as tillage practices are decreased, yet does not appear to cause yield reduction

\begin{tabular}{lccc}
\hline \multirow{2}{*}{ Tillage system } & \multicolumn{3}{c}{ P soil test (P per acre) } \\
\cline { 2 - 3 } & & Soil depth & Maize yield ${ }^{1}$ \\
\cline { 2 - 4 } & 0 to 1 inches & 1 to 3 inches & 49 pounds \\
\hline Plow + 2 diskings & 49 pounds & 45 pounds & 65 pounds \\
\hline 2 diskings & 121 pounds s & 113 pounds & 34 pounds \\
\hline No-till & 157 pounds & 123 pounds & 90 bushels per acre \\
\hline
\end{tabular}

${ }^{1} 12$-year average maize yields

Note: 1 pound $=0.454 \mathrm{~kg}, 1$ bushels/acre $=1 \mathrm{x} 0.6277$ quintals $/ \mathrm{ha}$.

Since soils warm more slowly under crop residue, it is recommended that a starter fertilizer application of nitrogen and phosphorus through the planter be used to get maize off to a more rapid start.

Apply nitrogen based on the yield potential of the soil, using a rate of 1.0 pound $(0.454 \mathrm{~g})$ to 1.15 pound $(520 \mathrm{~g})$ of nitrogen per acre (0.404 ha), per bushel (15.42 kg) of expected maize yield. On loamy sands, sandy loam soils,

or soils with poor drainage, it is desirable to split the nitrogen with one-third of the nitrogen applied at planting and two-thirds of the nitrogen applied when maize is 6 inches to 18 inches tall. Significant quantities of urea nitrogen can be lost through volatilization when applied on crop residue. The efficiency of liquid nitrogen can be improved by dribbling side dress nitrogen between the rows when maize is 6 inches to 18 inches tall. Do not 
broadcast liquid nitrogen over maize after it is 2 inches tall, due to risk of severe foliar burn. Ammonium nitrate or urea can be broadcast over maize that is 6 inches to 18 inches tall, but the maize foliage should be dry to reduce leaf injury. In a study carried-out by Dahal et al. [4] in Rampur revealed that the yield advantage from recommended doses of fertilizer (180:115:160 kg NPK ha ${ }^{-1}$ ) was $132.60 \%$ more over farmers' practice of fertilizer management.

\subsection{Date of Planting}

Soil temperatures at the $5-7 \mathrm{~cm}$ depth can be $2^{\circ}$ centigrade cooler under no-tillage system than in conventional tillage. Optimum maize germination occurs when midmorning soil temperatures reach approximately $50^{\circ} \mathrm{F}\left(10^{\circ} \mathrm{C}\right)$ at the planting depth. It has been found that no-tillage maize can be planted about a week later than conventionally tilled maize.

\subsection{No-Tillage Planters}

The selection and adjustment of no-tillage planters depends on the amount and type of residue cover, the soil type, and soil moisture. Planters should cut through residue cover and provide uniform placement of the seed in the soil at the proper depth to achieve good seed contact with the soil. No-tillage planters must firm the soil around the seed to ensure good germination and quick seedling emergence. Planters equipped with double-disk seedfurrow openers are recommended for no-tillage planting. Narrow, single, or dual-press wheels may be used for firming the soil around the seed. The adjustment and operation of planters should be in accordance with the manufacturer's recommendations.

It is important to avoid excessive speeds while planting to ensure correct planter operation once it is adjusted for the field setting. If the planter cannot be set to obtain adequate soil-to-seed contact, one should assume a 10 percent to 15 percent stand loss when determining the seeding rate per acre (0.405 ha). For a final population of 22,000 plants, approximately 26,000 seeds per acre (0.405 ha) i.e. (54,320 ha-1) are needed. More details on setting planters can be found in Planter/Drill Considerations for Conservation Tillage Systems, Virginia Cooperative Extension publication 442457 (http://pubs.ext.vt.edu/442/442-457/442-457.html). Under most conditions, seeds should be planted $3 \mathrm{~cm}$ to 6 $7 \mathrm{~cm}$ deep. When soils are cold or wet, it is advisable to plant the maize only $3 \mathrm{~cm}$ deep, but always ensure complete coverage of the seed. In the Terai and inner Terai of Nepal, a hybrid of 150 days crop duration during winter having grain yield of $8-10 \mathrm{Mg} \mathrm{ha}^{-1}$ can be planted at 66,666 plants ha- ${ }^{-1}$.

\subsection{Weed Control}

Weed control in no-tillage maize is often more difficult than in conventionally tilled maize. As a general rule, herbicide effectiveness decreases with the amount of crop and weed debris on the soil surface. This debris ties up herbicides and also presents a physical barrier to the uniform distribution of the herbicide on the soil for residual activity. Consequently, selection of herbicide rates and application methods is critical. Read and follow instructions on the herbicide label. On the other hand, residue cover provides some suppression of many weed species. In addition, there is generally less incidence of large-seeded weeds in continuous no-tillage systems.

Moreover, the result obtained in the first season experiment of tillage and weed management methods on spring maize at Rampur, Chitwan by Shrivastav et al. [14] revealed that the weed control efficiency and weed index vary due to weed management methods (Table 2). In which, herbicides of atrazine @0.75kg a.i./ha + glyphosate@2.5 ml/litre of water as pre emergence spray with tank mixture was found to effective in terms of weed control efficiencies and weed index (Table 2).

Table 2. Weed control efficiency (WCE) \% and weed index (WI) \% as influenced by tillage and weed management methods in spring maize at NMRP, Rampur, Chitwan, Nepal, 2013

\begin{tabular}{|c|c|c|c|c|c|}
\hline \multirow[t]{2}{*}{ Treatments } & \multicolumn{3}{|c|}{ Weed control efficiency(WCE) \% } & \multicolumn{2}{|c|}{ Weed Index } \\
\hline & 30 DAS & 60DAS & 90 DAS & Harvest & $(\mathrm{WI} \%)$ \\
\hline \multicolumn{6}{|l|}{ Tillage methods } \\
\hline Zero & 42.56 & $54.59^{\mathrm{a}}$ & $41.99^{\mathrm{a}}$ & $35.09^{\mathrm{a}}$ & $11.38^{\mathrm{b}}$ \\
\hline Conventional & 42.54 & $45.18^{\mathrm{b}}$ & $30.00^{\mathrm{b}}$ & $30.30^{\mathrm{b}}$ & $18.39^{\mathrm{a}}$ \\
\hline $\mathrm{CD}(\mathrm{P}=0.05)$ & NS & 6.68 & 6.63 & 3.92 & 0.98 \\
\hline SEm \pm & 1.50 & 1.09 & 1.09 & 0.64 & 0.16 \\
\hline \multicolumn{6}{|l|}{ Weed management methods } \\
\hline Weedy check & - & - & - & - & $37.17^{\mathrm{a}}$ \\
\hline Weed free( hand weeding) & $83.38^{\mathrm{a}}$ & $93.83^{\mathrm{a}}$ & $93.05^{\mathrm{a}}$ & $91.92^{\mathrm{a}}$ & $0.00^{\mathrm{f}}$ \\
\hline Atrazine & $30.28^{\mathrm{c}}$ & $36.87^{\mathrm{d}}$ & $17.85^{\mathrm{e}}$ & $11.36^{\mathrm{d}}$ & $23.58^{\mathrm{b}}$ \\
\hline Atrazine+Glyphosate & $53.73^{b}$ & $70.25^{\mathrm{b}}$ & $42.67^{b}$ & $36.83^{\mathrm{b}}$ & $6.31^{\mathrm{e}}$ \\
\hline Atrazine+ Pendimethalin & $43.52^{\mathrm{b}}$ & $47.98^{\mathrm{c}}$ & $24.67^{\mathrm{d}}$ & $22.72^{\mathrm{c}}$ & $12.74^{\mathrm{c}}$ \\
\hline Atrazine+ HW@40 DAS & $44.40^{\mathrm{b}}$ & $50.38^{\mathrm{c}}$ & $37.72^{c}$ & $33.35^{\mathrm{b}}$ & $9.51^{\mathrm{d}}$ \\
\hline $\mathrm{CD}(\mathrm{P}=0.05)$ & 12.72 & 2.87 & 2.38 & 4.11 & 1.48 \\
\hline SEm \pm & 4.04 & 0.91 & 0.75 & 1.31 & 0.47 \\
\hline CV\% & 21.67 & 5.93 & 4.76 & 10.35 & 5.13 \\
\hline Grand Mean & 42.55 & 49.88 & 35.99 & 32.69 & 14.88 \\
\hline $\begin{array}{l}\text { 3.6.1. Control of Exis } \\
\text { The types of weec } \\
\text { cover determine the }\end{array}$ & on at $\mathrm{Pl}$ & $\begin{array}{l}\text { ue } \\
\text { ed }\end{array}$ & \multicolumn{3}{|c|}{$\begin{array}{l}\text { to control vegetation present at planting. It is necessary to } \\
\text { consider the burn down materials (herbicides) and the post } \\
\text { emergence characteristics of the other herbicides to be } \\
\text { used in relationship to the weed infestation. }\end{array}$} \\
\hline
\end{tabular}


Annual grasses and broadleaf weeds can be controlled with nonselective herbicides, such as glyphosate or paraquat. When planting in perennial grass sods, a single paraquat application may not be sufficient to give satisfactory control. The use of glyphosate should be considered for control of existing perennial broadleaf and grass weeds at planting. Care must be taken to allow these weeds to reach the minimum growth stages listed on the label before application is made. Often, this delays the maize planting to the point that alternative crops or tillage methods should be considered as a means of control. The use of glyphosate should also be considered when heavy infestations of annual weeds are present and have advanced to the stage at which paraquat will give only partial control.

\subsubsection{Control of Annual Grasses}

Simazine has good activity on annual grasses, and a combination of atrazine and simazine will give good control, especially of late-season flushes of these annual grasses. Chloroacetamide herbicides, including metolachlor, alachlor and acetochlor, also provide good residual control of annual grasses and suppression of yellow nutsedge. These herbicides can be used in combination with atrazine, or in combination with atrazine and simazine [11].

\subsubsection{Control of Perennial Broadleaf Weeds}

In NT maize plantings, herbaceous perennial broadleaf weeds can become very problematic. These species must be controlled with systemic herbicides at growth stages when translocation towards underground perennial plant structures is maximized. Generally, these perennials have not emerged at the time of planting, and making applications before planting are ineffective [11] to match their specific infestation to the most effective treatments. Growers should also consider control of these perennials in rotational crops.

\subsubsection{Control of Perennial Grasses}

There are several excellent post emergence methods for perennial grass control in no-till maize. Johnsongrass (Kans) can be controlled with nicosulfuron. Several postemergence herbicides, including halosulfuron, mesotrione, and glyphosate, can be used for the control of yellow nutsedge.

\section{Trade-offs of the NT}

- Transition from conventional intensive tillage based farming to no-till is difficult

- Necessary equipments and farm machines are costly

- Mainly dependence on herbicides

- Prevalence of weeds, disease and other pests may shift in unexpected ways

- May initially require more nitrogen fertilizer and

- Can slow germination and reduce yields in the first one or two ]seasons.

\section{Some of the Tips for Implementing First Time the NT Maize in the Hills of Nepal}

- The remains of previous crop should be kept lying in the furrows soon after harvest or collect leaf litters from the forests sufficient to cover the cropped area.

- Slash all weeds before they mature and produce seed.

- Wait for the first good rains before using the postemergence herbicide.

- If the rain has been good and you feel that maize can be planted after ten days then, it is time to start thinking of applying the post-emergence herbicides like glyphosate.

- In order to apply the post-emergence herbicide, glyphosate, weeds grown with the rains should reach $15 \mathrm{~cm}$ above the ground. Glyphosate should be applied in a 15 litres knap-sack sprayer. In general, 15 litres of mixture of water plus chemical at one meter per second step is enough to spray one tenth of a hectare. For one tenth of a hectare, it is necessary to mix 400 to $500 \mathrm{ml}$ of Round-up with approximately 15 litres of clean water (Avoid salty water). When applying the chemical, do it about $25 \mathrm{~cm}$ above the weeds. It is important that the nozzle is not dirty with soil since the chemical will be depleted and will lose its action as herbicide.

- After 2 to three days of the application, the weeds start dying. Then after another two to three days, planting can start. Plant one seed per hole at $25 \mathrm{~cm}$ apart on ridges spaced at $75 \mathrm{~cm}$.

- At the same time of planting supply the basal fertilizer. It is recommended to supply approximately 9 grams of Urea (23 kg of Nitrogen) mix with 1.8 grams of 23-21-00 (23 kg of nitrogen plus $21 \mathrm{~kg}$ of phosphate). This is equivalent to one bag of Urea per hectare plus two bags of 23- 21-00 per hectare. The mixture of both fertilizers should be done at the same time that the fertilizer will be supplied between two plant stations. The fertilizer should be incorporated and covered at about $5 \mathrm{~cm}$ into the ground. Use a bottle top without the plastic lining filled at water level to supply the 2.8 grams mixture of both fertilizers.

- After planting and supplying the fertilizer, immediately apply the preemergence herbicide Atrazine. The application of Atrazine should be done with the same knap-sack sprayer using 15 litres of water mixed with 45 gram of it. One sprayer is enough for one tenth of a hectare. Use the flat fan nozzle as the one used in applying glyphosate.

- Wait until the maize has reached knee high to supply the topdressing fertilizer. Use 1.8 grams of urea per plant to supply two bags of urea per hectare (46 kg of nitrogen). Use a bottle top with the plastic lining filled at water level to supply the 1.8 grams of Urea.

- Uproot the weeds left out during spraying. Do not disturb the soil and wait until the physiological maturity of the grain to harvest.

\section{Conclusion}

In Nepal, maize is grown under intensive tillage ssystem of 2-3 ploughings for land preparation and atleast two intercultural operations for weeding and earthling-up 
operation. Alternative to conventional tillage system, notill system is a specialized type of conservation tillage consisting of a one-pass planting and fertilizer operation in which the soil and the surface residues are minimally disturbed. No-tillage maize production conserves soil and water and reduces capital investment in machinery for land preparations and intercultural operations, but most important to many producers, no-tillage can improve maize yields. Despite the immense benefit and need of no till in Nepal, it has some trade-offs too. The practical tips for the inception of no till maize production promise the hope of it in Nepal.

\section{References}

[1] ABPSD. Agri-Business Promotion and Statistics Division. Ministry of Agricultural Development, Government of Nepal, Kathmandu, Nepal, 2012.

[2] Bescansa, P., Imaz, M.J., Virto, I., Enrique, A. and Hoogmoed, W.B. Soil water retention as affected by tillage and residue management in semiarid Spain.

(www.wageningenur.nl/en/Publication-details.htm?publicationId), 2006.

[3] Carter, M.R. and Rennie, D.A. Soil temperature under zero tillage systems for wheat in Saskatchewan. Can. J. Soil Sci., 65: 329-338, 1984.

[4] Dahal, S., Karki, T.B., Amagain, L.P. and Bhattachan, B.K. Tillage, residue, fertilizer and weed management on phenology and yield of spring maize in Terai, Nepal. Int. J. Appl. Sci. Biotechnol, Vol 2(3): 328-335.

[5] Edwards, W. and D. Smith. 2005 Iowa custom farm rate survey. Ames: Iowa State University.

(http://www.extension.iastate.edu/publications/FM1698.pdf), 2005.

[6] Johnson, J.M.F., Reicosky, D., Allmaras, R., Archer, D. and Wilhelm, W.W., A matter of balance: conservation and renewable energy. J. Soil Water Conserv. 61, 120-125, 2006.
[7] Karki, TB., Gadal, N. and Shrestha, J. Studies on the conservation agriculture based practices under maize (Zea mays L.) based system in the hills of Nepal. Int. J. Appl. Sci.Biotechnol, June 2014 Vol 2(2): 185-192, 2014.

[8] Lal, R. No-till Farming. International Institute of Tropical Agriculture. Monograph3, 1983.

[9] Moschler, W. W., Shear, G. M., Martens, D. C., Jones, G. D. and Wilmouth, R. R. Comparative yield and fertilizer efficiency of notillage and conventionally tilled corn. Agronomy Journal 64: 229231, 1972.

[10] Parr, J.F. Papendick, R.I., Hornick, S.B. and Meyer, R.E. The use of cover crops, mulches and tillage for soil water conservation and weed control, In: Organic matter Management and Tillage in Humid and Sub-humid Africa. IBSRAM Proceedings No. 10. Bangkok; IBSRAM. Pp. 246-261, 1990.

[11] Pest Management Guide. Field Crops, Virginia Cooperative Extension publication 456-016. (http://pubs.ext.vt.edu/456/456016/456-016.html), 2009.

[12] Pikul Jr, J.L., Johnson, J.M.F., Schumacher, T.E., Vigil, M. and Riedell, W.E. Change in surface soil carbon under rotated corn in eastern South Dakota. Soil Sci. Soc. Am. J. 72, 1738-1744, 2008.

[13] Reicosky, D. C. and Allmaras R. R. Advances in tillage research in North American cropping systems. J. Crop Prod. 8: 75-125, 2003.

[14] Shrivasta, N., Amagain, L.P., Basnet, K.B. and Karki, T.B. Weed dynamics and productivity of spring maize under tillage methods and weed management in Rampur, Chitwan. M.Sc Thesis. Tribhuvan University, Nepal, 2014.

[15] Varvel, G.E. Soil organic carbon changes in diversified rotations of the Western Corn Belt. Soil Sci. Soc. Am. J. 70, 426-433, 2006.

[16] West, T.O. and Post, W.M., Soil organic carbon sequestration rates by tillage and crop rotation: a global data analysis. Soil Sci. Soc. Am. J. 66, 1930-1946, 2002.

[17] Wilhelm, W.W., Johnson, J.M.F., Karlen, D.L. and Lightle, D.T., Corn stover to sustain soil organic carbon further constrains biomass supply. Agron. J. 99, 1665-1667. West and Post (2002). 2007. 